\title{
"You're Freer If There's Nobody Around": "Gay Women's" Space in Small-Town Ontario
}

\author{
Liz Millward \\ SARAH PAQUin
}

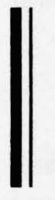

Liz Millward teaches in the School of Women's Studies at York

University. Sarah Paquin lives and works in Toronto. An earlier version of this article was presented at the Canadian Lesbian and Gay Studies Association conference at the University of Toronto in May 2002.

\section{Introduction}

T $\mathrm{n}$ this paper we interrogate how women in a small town in Ontario who define themselves as "gay" attempt to produce 1 spaces, at different scales, that both challenge the perceived heteronormativity of the town and allow them to sustain their identities. Through the data collected during interviews with nine women from a town in Ontario that we are calling "Waterside," 2 we argue that these women offer a partial challenge to the widely held belief that small-town life is inherently heterosexual. We begin with

${ }^{1}$ Only one of the interviewees said that she would use the term "lesbian" to describe herself. All of the interviewees said that they would use the term "gay," and one expressed intense dislike of the term "lesbian," preferring "queer" but using "gay" on occasion. In order not to misrepresent the women we use the term "gay" to refer to the interviewees but "lesbian" when we refer to the literature.

${ }^{2}$ With the exceptions of Toronto, Vancouver, and Ontario, we have given pseudonyms to all of the Canadian places and people in this paper. We worked with a gay women's community that allows access only to those who agree to maintain the strict anonymity of its most vulnerable members. Permission to use the interviews was based on our agreeing to maintain the anonymity of the group, even if some individual members of the group were 'out.' 
a brief discussion of existing literature, the location of our study, and our research methodology. Our primary analytic tools come from critical human geography. Then, we explicate the ways in which geographers analyze the links between space and social relations, focusing in particular on the concept of scale. We proceed to examine three scales through which our respondents generate spaces that they can use to reproduce and sustain a fourth scale, the gay women's community. We conclude by considering the implications of our tentative findings for further research and by outlining the questions that our findings raise about the nature of small-town spaces and women-only communities.

\section{Existing Literature}

The existing geographical literature refers on the whole to lesbian spaces rather than gay women's spaces. Terminology is political, and geographers' discussion of "lesbian" spaces may indicate the researchers' contact with politicized and feminist communities. Given that the women we interviewed explicitly rejected the term "lesbian" and described themselves as "gay," we refer to them as "gay women." We presume a commonsense, although highly contested, definition of "lesbian" and "gay woman" in which both refer to women who are sexually involved with other women; we do so in order to draw on the literature that discusses the geography of lesbian spaces. This literature is divided between discussions of the urban and the rural. Some authors - such as Sy Adler and Johanna Brenner, Ann Forsyth, Tamar Rothenberg, and Gill Valentine - have examined the production of lesbian urban spaces. Literature on rural lesbians tends to refer to women-only land colonized by urban lesbians who seek an idyll where they may create nonoppressive forms of living and community. As such it tends to be an overtly feminist space (Bell/ Valentine, "Queer Country" 118-19; Valentine, "Making Space" 6769). One exception is Linda McCarthy's work on the ways rural lesbians in the USA sustain their identities. Existing geographical literature on lesbian spaces is also overwhelmingly limited to the UK and the USA, with some work, such as Elsie Jay's, on Australia. There are some contributions to the literature on lesbian spaces in Canada, such as Julie Podmore's work on lesbians in Montréal, and Anne-Marie Bouthillette's and Jenny Lo and Theresa Healy's work on Vancouver, but these are examinations of lesbians in urban spaces. 
All of this geographical literature raises questions about how space is sexualized, or how sexuality is reproduced through space. Given the absence of discussions about nonmetropolitan areas our interest is in whether small towns, which lack the diversity of metropolitan areas and provide limited access to resources but do have industry, might be significant spaces where gay women have enough economic opportunities to remain where they were born and brought up rather than migrate to a big city (Weston 254). We are not so much concerned with their development of identities as with their ability to create and negotiate spaces in which they can sustain their community. Our access to one particular small town in Ontario suggested a starting point for this question.

\section{Waterside}

Waterside is located in Ontario. It has a population of just over 20,000. According to the Canadian census definition Waterside would just fall into the category of "small nonmetropolitan city" rather than that of the "small town." It would also fall into the category of "census agglomeration" 3 of which there are 68 in Ontario. It consists of an older, compact, downtown core located on the waterfront, and a newer, large, sprawling industrial and service area that includes gas stations, factories, malls, and residential neighborhoods. Waterside is surrounded by farmlands and very small towns and villages whose residents use the social services and entertainment facilities available in the town. Its economy is based on a diverse range of manufacturing industries.

Class differences are clearly evident among the residents of Waterside and are organized spatially through where people work, live, and go to school. Over 95 per cent of the population identify as white, and the remainder comprise aboriginal and a multiplicity of "visible minorities." English is the predominant language. There are no mosques, synagogues, or temples. There is approximately one church per 650 people. The majority of these churches are of protestant denomination. Entertainment and socializing center around churches, pubs, bars, restaurants, pool halls, a bowling alley, a movie

${ }^{3}$ The term census agglomeration refers to one or more adjacent municipalities centered on a large urban core. To form a census agglomeration the population count of the urban core must be at least 10,000 and less than 100,000 . 
theater, a bingo hall, and seasonal outdoor sports. There are no lesbian or gay entertainment facilities or social services. The video stores and public library offer virtually no identifiably queer-positive resources, texts, or videos. Beyond the scale of individual lesbian and gay bodies, which may at times be read as such, there are arguably no (positive) institutionalized representations of lesbian or gay sexualities or individuals in the spaces of Waterside. To the extent that any place is representative, Waterside offers an example of a typical small nonmetropolitan city, commonly referred to as a "small town," in anglophone south-western and south-eastern Ontario.

\section{Research Methods and Theoretical Considerations}

Learning of the authors' research interest in lesbian space, three young heterosexual and bisexual women from Waterside volunteered information about their experience of public space in the town. They argued that it was defined as heterosexual in a homophobic discourse. They expressed resentment about the restrictions that heterosexist comments about Waterside necessarily attempt to place on their own gender and sexual identities. Their examples raised questions for us about how the heterosexualization of small-town space might be replicated and challenged by the gay women living in it. All of the interviewees were selected because one of the authors had insider status with them. Access to the larger gay women's community was facilitated by an insider relationship with one of its members.

This paper is based on data collected from unstructured interviews with three young heterosexual and bisexual women (1618 years of age) and six gay women (27-55 years of age). All of the respondents, with one exception, grew up or went to school in the Waterside vicinity. Five grew up in Waterside and three grew up in smaller villages nearby. Seven went to school in Waterside and one went to school in the surrounding area. Seven live in Waterside and two live in smaller villages. One of the respondents currently has health problems and is not working, but all of the other respondents work in Waterside. They work in a range of occupations including retail, nursing, middle-management in a factory, construction work, mission work, social work, and work in the Armed Forces. All of the gay women have identified as gay for most of their adult lives with the exception of one who had been married and has two grown children and two grandchildren. She has been a part of the gay 
women's community in Waterside for approximately 14 years. None of the interviewees disclosed their ethnic identity to us.

In interviewing the women, we asked them to clarify what terminology they use to identify themselves and about their use of space in the home, yard, and town. We also asked about the sorts of lesbian or gay signifiers, such as T-shirts, necklaces, and buttons, that they wore. These questions elicited a complex understanding of how they utilized differing spatial scales.

The number of interviewees from whom data was collected is small and their experience cannot necessarily be assumed to represent the experiences of all young heterosexual and bisexual women or gay women in Waterside. Therefore any conclusions drawn from this research are necessarily partial. Nevertheless, the data provides insight into the sociospatial regulation and reproduction of gendered space and sexuality in a small-town Ontario context.

As a category of analysis, space itself is multiform. It is emotional, mental, and physical. Its physical form includes the built environment and landscape. Physical spaces are social spaces inasmuch as each type of physical space - a school playground, a home, a highway - has meaning and social significance, and each functions, in contested ways, to reproduce social differences such as age, gender, and class. Space is produced by ideological forces and power relations. Spaces make these visible and at once naturalize them by means of walls, windows, tower blocks, fences, etc. Tim Cresswell argues that through this process of spatial naturalization some beliefs, behaviors, and bodies appear to be "in place," while others are positioned as "out of place" in both the geographical and social sense (154). This demarcation of particular people and practices as being "out of place" in any given context constitutes the 'othering' of nondominant bodies, practices, and ideologies. Social space is structured by normative understandings of gender in the sense that they define who should be included and excluded from access to particular spaces. Women, for example, are under ideological pressure to locate themselves most properly in domestic or private space, leaving public space to men (McDowell 71-95).

Judith Butler complicates notions of gender by pointing to gender intelligibility, which relies on the performance of gender, sexual desire, and sexual practice in continuity and coherence with the "sex" of a given body (17). Just as bodies are not inherently sexed 
or gendered and come into being through the performance of a "stylized repetition of acts" (140), so too is space a product of performativity. Thus, we maintain that space is not only gendered but also necessarily sexualized. The demarcation of public and private replicates the perceived binarism of heterosexuality. The volume of heteropatriarchal imagery in billboard, bus shelter, and window advertisements, the dearth of equivalent lesbian imagery, the critical mass of apparently heterosexual actions (such as opposite sex flirting, hand holding, and kissing), and the paucity of similar apparently lesbian actions combine through everyday repetition to build up a sense of space as naturally heterosexual. David Bell, Jon Binnie, Julia Cream, and Gill Valentine further explicate the socially constructed nature of space as heteropatriarchal, stating that, like gender and sexuality, space is not intrinsically heterosexual, but is actively produced as heterosexual through the repetitious performances of identities informed by the workings of the heterosexual matrix (45; see also Valentine, "(Hetero)Sexing Space" 409-10).

The naturalization of heterosexualized space is open to contestation and does not manifest itself in a singular unified way across all spaces. Particular spaces are sexualized in different ways, despite the normalization of heterosexuality. One way to think about how such a process happens is through the concept of scale.

In his article on the significance of scale Neil Smith argues that scale is the level at which social relations are understood to be organized. He lists the scales of the body, home, region, nation, and the globe (102-13). The production of scale, for example the definition of a particular place as a region, creates a site of "intense political struggle," because it is through scale that social differentiation takes place (97-99). The new "regional identity" of the inhabitants of a place may come into conflict with those of a different "region." According to Smith different kinds of places are distinguished from one another through the scale at which their meanings are understood. For example, the difference between levels of government and what each is responsible for is naturalized in space, as if space creates natural boundaries between levels of government - municipal, provincial, federal. As Neil Brenner argues in his discussion of urban theory, "scales operate simultaneously as territorial containers and as geographical hierarchies of everyday power relations under capitalism" (374). Smith's definition of scale 
and Brenner's discussion are primarily concerned with economic power relations.

Sallie Marston extends the definition of scale to suggest that particular groups may utilize power relations at one scale to access power through another scale that exceeds economic considerations. In her example, late nineteenth-century American middle-class urban women used the scale of the home for "social and political identity formation." Domestic ideology legitimated their power through this scale, and from this base they then extended "their influence beyond the home to other scales of social life" such as municipal housekeeping (235). In the process they actively produced spaces through which they reproduced and also challenged the naturalization of social relations at different scales. Susan Ruddick adds that "there is no necessary correlation between the physical scale at which a public space is constituted and the scope of its public realm" (140). A small space - such as a yard - can be invested with the function of reproducing the (heterosexual) identity of its occupants. Space, then, functions to naturalize social differences and scale divides the geographical level of that naturalization. Thus, there may be an assumption that lesbians and gay men exist in the nation but they may be assumed to be absent from the town.

In this paper we look at three scales - the body, the home and yard, and the town - in order to discuss how the gay women's community in Waterside produces space. We utilize scale to analyze the spatial expression of sexuality since, just like the economy, sexuality is a field that is subject to and a product of competing ideologies. We unpack the scalar levels of meaning in gay women's spaces.

\section{Bodies}

For the gay women interviewees the scale of the body is a site both of possibility and of challenge. It provides a means by which they recognize each other and a site of safety from epistemic and/or physical violence. In accordance with Valentine's study ("Negotiating and Managing" 241-45), gay women in Waterside all employ what she terms "time-space strategies" through which they are more or less out at different times, in different places, and to different people.

The interviewees use their bodies for expression in many ways, but only three behaviors are of relevance to our research. First, they negotiate how heterosexuals read their bodies. Kelly, for example, 
drew attention to the T-shirt she was wearing that featured two female cartoon characters kissing: "But it's the first time I've felt comfortable wearing it out; but I know where I was going, I had to get in that headspace, where you know where you're going to go ... I've just recently shaved my legs and I know I couldn't have a summer of not shaving my legs in this town because people are like ... fuck! What the fuck?" Here, Kelly suggests that while she can wear a Tshirt to indicate her sexuality, defying gender norms is more difficult. Her gender performance in turn complicates her degree of visibility. She acknowledged that she can pass as heterosexual and that who she was with in public determined how her sexuality was read: "But going out, it depends who you go out with because I can play both sides, it's very easy to pass either way" (Kelly). Her singular body is insufficient to signal her sexuality without the T-shirt, and can only produce gay women's space when associated with another body. This means she is frequently confronted with the choice to activate what she defines as "queer" space through her selection of clothing, her presentation of her body (shaved or hairy legs), and her choice of company.

The body can also serve to exclude a woman from gay women's space, since the second use of the body is as an identifier for other gay women. This generates a space that is populated with women they can recognize and who are similar to themselves. Kelly's ability to "pass either way" means that she is sometimes misread by other gay women or lesbians. Referring to a coffee shop run by a lesbian, Kelly remarked: "But even when I go in there that woman is just cranky, like I don't go in there and feel comfortable because I go in there and I'm like, first of all you don't recognize me, you don't recognize me as in your subculture." This use of the body to reproduce gay women's space clearly limits the contours of that space, as Kelly attests. Dana implicitly acknowledged the limitations: "But I think there's a larger community of gays in Waterside than we know."

A third use of the body is to produce gay women's space en masse and confront homophobic behavior. Dana expressed irritation with the oversexualization of gay women, through which they were perceived as sexual predators with diseased bodies:

You know people are very closed minded. You know it's not like I'm going to jump all over them just because you 
know I'm gay and I see you outside and like I'm going to take you to bed or whatever. That's what people think, you know ... Because they're afraid they're going to catch something when I shake ... Well, to the point where at a ball game, Joanne and Pam and Cathy and Diane and all the girls on the ball team and they would shake hands with the other ball team. You know the girls would go like this and wipe their hands on their pants because they knew that they were gay and they didn't want to catch anything. It was very obvious at ball games ... Well I mean, you know, give me a break. (Dana)

In response to the heterosexual ball-players' fear of contamination through touch, the gay ball-players at the next game returned the insult, wiping their hands after shaking with the opposing team. Overall, in the absence of public spaces, gay women in Waterside use their bodies to manage heterosexist and homophobic situations and ultimately to create gay women's spaces. These uses of the body to produce space are especially useful in Waterside because there are no institutional spaces (bars, clubs, community events) where they can assume everyone present is a gay woman. In the absence of identifiable and demarcated social spaces it is by means of their bodies that the gay women interviewees challenge the construction of Waterside as a heterosexual space.

\section{Homes and Yards}

Smith refers to the scale of the home as the "heavily gendered site" of "personal and familial reproduction" (104). Feminist geographers have examined the ways in which lesbians create sociosexual spaces in their homes. Sarah Elwood identifies contradictory meanings of home for lesbians. Her research reveals that some lesbians assert their sexual identity and challenge presumed heterosexuality by using visible signifiers on the outside of their homes, such as rainbow flags and posters (17). Her study is based on a uniquely politicized lesbian feminist community in the United States, whereas we argue that in Waterside the respondents challenge assumed heterosexuality and counter latent homophobia through the scale of the home in necessarily different ways. The first way concerns the inside of the house itself, and the second concerns the semipublic space of yards. 
Kelly, Brenda, and Fiona all discussed the ways in which they manage the competing meanings of home inside the house. Kelly lives with her mother and much younger sister in "Willowville," a village outside Waterside. Asked whether she has any queer possessions in the home, she replied:

Well, it's hidden, all my on our backs editions, and all my pictures ... I don't put any of that up, well actually my calendar, I am and I'm not, I'm at the point where I don't want to have to feel like I'm a dirty little secret anymore, I don't want to and I don't think I should ... but it's easy when you say that when you're single and it's not in your face. You know, all of a sudden I bring someone home and say can we sit here and hold hands on your couch? Or, you know, we're going to bed now ... that's going to be a completely new foreign ground for her to handle ... my ex and my other friend made me a calendar, boys who are girls, something like that, something really clever, and some really nasty dirty awesome genderfucked pictures and I thought I love this calendar this is my life, my calendar, you know, I've had it up since I got it May last year and I thought I'm going to put it up and I put it up in the closet, but the door was closed [laughter] I know but the door was always open, it was on the other side of the closet so I thought well if someone comes in I'll just shut the door, but I showed her [her mother] the calendar, I put it up, you know, and it was like, baby steps, you know, baby steps. (Kelly)

Kelly expresses here the complex negotiations around sharing her home with her mother. She feels pressure to hide the material that affirms her identity, yet is also prepared to work through her mother's response to the material at her mother's pace. Yet she acknowledges that this process is easy as long as she does not introduce another gay or "genderfucked" body into the space. If she did, her mother would then have to confront the relational meaning of Kelly's identity.

Home-owners Brenda and Fiona, on the other hand, expressed ambivalence toward the visibility of possessions, such as pictures and clocks, that signified their identities, and toward their 'de-dyking' strategies for dealing with visitors. Their strategies vary:

It's pretty well de-dyked. Well, we had those pictures up on the wall of those two women. We took that down. Two nude 
women. When we went Christian. We went Christian maybe a year ago, two years ago. It was too odd ... or someone was going to sleep in our room ... (Fiona)

The nephews were over. (Brenda)

That's right, but it hasn't gone back up. (Fiona)

I thought stuff just kind of happened. Like the batteries in our clock went funky. (Brenda)

Well that's funny 'cause we do have a rainbow clock. That's just because we always keep that up. I don't consider that to be, I don't know ... And we've got stickers on our cars, gay stickers. I guess the pictures in the bedroom are what I saw as de-dyking. We took those down for the nephews. The [sex] toys are very well hidden. If any. (Fiona)

In the closet, but again, that's the nephews. Don't want them running around with those. (Brenda)

We've got our books upstairs but they're out in the open. But we did take them out of the room if somebody stayed there. My sister. (Fiona)

In spite of the confusion over why particular 'de-dyking' strategies were employed, Brenda and Fiona were adamant that in terms of affection they were not prepared to 'de-dyke' their relationship; Fiona remarked: "That is something that we've made a conscious decision on is within the house. We haven't really talked about it but ... because we respect other people when we're out so we might not hold hands. It depends on who it is. But if anybody comes over, straight, gay, whatever, we'll kiss, we'll hold hands." Clearly, Kelly's struggle is diametrically opposite to Brenda and Fiona's. Kelly insists on creating what she defines as a queer space in her room with objects such as a calendar; she is at once aware that a relationship would create a new level of territorial struggle over her use of the sofa or of her bed to express her sexuality through holding hands, kissing, or having sex. Brenda and Fiona conceal or remove the objects that attest to their sexuality and relationship, but are not prepared to forego affectionate interactions in front of visitors. All three women point to the contradiction in negotiating the interior of the home, a supposedly private space associated with the expression of identity, with the perceived expectations of visitors or other occupants. The presence of other bodies seems to create a sense of limitation on the women's claim to spatial autonomy in 
the home. This sense of limitation supports Johnston and Valentine's finding, in their comparative analysis of lesbians in New Zealand and the UK, that the scale of the home is overburdened with conflicting gendered meanings (111-12). These meanings complicate gay women's attempts to generate alternative versions of the "home."

Socializing in larger groups usually takes place indoors. Dana, Sam, and Martha referred to parties before Christmas, on New Year's Eve, and on long weekends, and to having people over to play cards or watch lesbian movies that had been copied from satellite dishes and distributed through the community. As Brenda explained, socializing with other gay women occurs, "Almost exclusively within people's homes with their yards ...We go to dances in 'Gladstone,' women's dances in Gladstone. Sometimes a couple of carloads of us will go up. But almost exclusively things like this." However, as Brenda indicated above, the women resist unspoken assumptions that expressions of their sexuality must occur only within the home. Although not intended as a direct political statement, they claim the territory of their yard as a legitimate but contested space for expression of their community. This expression ranges from individuals kissing to community gatherings during which no-one may kiss. Yet the mere presence of a women-only group provides a challenge to heterosexist assumptions about domestic space. These challenges are nonetheless always carefully negotiated around the participants' individual levels of comfort. Brenda, for example, explained that she and Fiona would "kiss on the porch and stuff like that. Like when I'm leaving for work ... I figure it's my yard. I wouldn't do it in somebody else's yard just out of respect for it being their yard. But in my yard, I mean ..." Brenda sees her yard as private even if it is overlooked by neighbors. Dana's understanding of the yard indicates that it can also be a semipublic space with varying degrees of privacy:

Mind you it's nice to have privacy when you get a gang together like last night ... The girls are usually pretty good with neighbors that are close like this ... Well I'm sure that they probably sat out on their decks last night [laughter]. They did across the way. You know ... Now out at Gina and Tammy's there's no neighbors, you know ... Just through the trees there's someone off to the side but not that they 
could see what was, not that we did anything, but you know, you're freer if there's nobody around. (Dana)

If the home is a scale through which heteronormativity is written into the geography of domesticity, yards appear to provide more opportunities for developing gay women's space. Yards are still subject to surveillance, but they are not as clearly gendered as the interior of the home. However, unlike homes, into which people are invited, yards may be overlooked by strangers and hostile neighbors. The interviewees expressed a shared sense that their actions had to take into account the possible negative reactions of others. Exercising such caution at the scale of the town was a more complex process.

\section{Town}

The town of Waterside is, as a geographical scale, most simply understood as the site where "capital and social resources devoted to social production, consumption and administration" are centralized (Smith 107). To the extent that it is large enough to produce differential land uses through differential ground rent levels, the town is a space in which social differences - that is, levels of income, access to resources, access to different areas within the town - are reproduced spatially. In this sense the very idea that Waterside is a 'small town' can be understood as a shorthand for particular forms of social relations: the role of local government in promoting particular local interests; rigid gender roles; heterosexuality; and hard-working self-reliant individuals. The roles of capital, gender, sexuality, and state power are reproduced in people's everyday lives as they move around the town negotiating areas where they are sometimes in place and sometimes out of place.

Every interviewee used the term "straight-laced" to describe the town. Kelly went so far as to condemn it as "small-time, small-mind, small-town, very white, very straight, very hard to ... it's straight and narrow, you don't deviate from the norm here. You do and you're excluded, you're alienated and you're ostracized, completely, from any community." Kelly's sense of the town as rigidly heterosexual was supported by the experiences of the heterosexual and bisexual high school students interviewed. A common sentiment in Waterside is that lesbian existence is solely an urban phenomenon. While this understanding is likely largely informed by the fact that lesbians and 
gay women in Waterside carefully negotiate their levels of visibility and do not strive for an obvious and continuous presence, it may also ensure the future invisibility of lesbians in Waterside. For example, the notion of lesbians as exclusively urban became an issue for a high school art class painting a mural that depicted employees working in a local factory. The students unintentionally created a woman (the only one in the mural) who "looked like a dyke":

We were almost finished, we just had the woman left and our teacher was practically freaking out. He kept saying, "give her more hair," "why does she look like a man," "make her look more feminine." Some of us were annoyed and we knew he didn't want her to look like a dyke so we said, "Why Mr. S, what's the problem?" He got all red and said, "Not that I care, but she looks like a lesbian." So I said, "So what, don't you think any lesbians work there?" He got all mad and said, "Don't say that. I don't think it's appropriate. This has to go on the wall you know. Where do you think we are, San Francisco?" (Becki)

This example reveals 'commonsense' notions about what can be 'appropriately' depicted in a deliberate representation of Waterside life and represented to the community as a scholastic, artistic endeavor by young people. Lesbians, it seems, are in place in San Francisco, but out of place in Waterside. Moreover, schools must be seen to replicate gendered distinctions of appearance and occupation. The mural depicts only one woman as a worker and she must have a feminine appearance, regardless of how inaccurately that may reflect Waterside's female workforce.

Jenna stated that while attending a lecture on driving safety with a group of other high school students, the conversation turned toward the out American comedienne Ellen Degeneres. The teacher asked one student, "You like that dyke? What are you, a lesbian [laughing]? Sorry, just kidding, I know you are not a lesbian.” As Jenna reports:

I was so mad and I said, "Why do you think you can always tell if someone is a lesbian?" He's so dumb he just said, "Because you can just tell and I sure don't know any." I told him that my sister is lesbian and he just laughed and said "Oh yah, who is she?" When I told him he doesn't know her because she lives in Toronto he said, "Well that explains it. What do your parents think about what happened to her in the big city?" (Jenna) 
Such statements concerning the urban construction of lesbians and of small town impossibility are profoundly invested in the notion of natural and original female heterosexuality that permeates the scale of the town. Individual bodies may lose their heterosexuality but only through a spatial shift. The gay women know that their presence unsettles the scalar function of the town to reproduce heterosexual space. By contrast, these men's statements insist that the scale of the town is secure. They work to reinscribe this security by refusing the possibility of unknown (to them) lesbian bodies that might denaturalize the presumed heterosexual contours of Waterside. These men's homophobic invocations of the urban/small town dichotomy as one of vice/virtue and lesbian/straight gain discursive legitimacy from their roles as teachers.

In another example of the reproduction of the town as a heterosexual site, the young bisexual interviewee remembered a conversation she had with a local real estate agent who expressed disgust after attending a business function. According to Carla, the real estate agent said: "'I hate going to all these dinners in Toronto and Ottawa with all the flashy queers. They just work to represent the 'gay community.' She [a lesbian real estate agent] just got up there and started talking about servicing [sic] the 'gay community' this and serving the gay community that. Like, as if this is relevant to us. Why do we have to sit through that?"' (qtd. by Carla). The "us" clearly denotes a heterosexual population that is assumed to constitute not just the real estate agent herself but the entirety of the small town in which she works. Again, the town is imagined as a purely heterosexual space by this woman. In her work she may well replicate that assumption, selling only to buyers she perceives as heterosexual. Her imagined assumptions about the town may thereby become concretized in its residential neighborhoods.

The young heterosexual and bisexual women encountered vehement denials of lesbian possibility in the town, and the teachers and real estate agent actively produced the space as heterosexual. In this context, the gay women have to negotiate the tension between their own physical presence in the town and the townspeople's construction of it as a heterosexual space in which they are out of place. Kelly described this tension as, "draining because you're constantly worried about, well, not worried but on guard about what people are going to react to, and how are they going to react, and 
what are they going to do, how they're going to act, and then you have to constantly defend what you're trying to do when you're just trying to go to the bank, use the machines, eat in a restaurant, you know I don't need that kind of stuff." Kelly's experience signals how the intersection of two scales - the body and the town - is a site of struggle over social relations. Her need to be "on guard" suggests that social surveillance is a key element in the contest between those inhabitants determined to heterosexualize the town, those determined to challenge them, and those made uncomfortable by their position within the town. Fiona indicated how the fear of surveillance affected the behvavior of some gay women: "Like somebody was here today and I was outside and you and I were hugging or something and somebody said 'Oh I'm just going to move around this way because I know people across the street." Kelly also mentioned the complex role of social surveillance in the town and its effect on her activities. A coworker reported to Kelly a conversation he had had with another coworker: "she said she had seen you downtown and you were with a really butchy woman." Of course, the intersection between the body and town also occurs in larger urban areas, but the lack of anonymity in the town - "I know people across the street"; "she said she had seen you" - means that gay women cannot control the processes of recognition and safety when they are in the town. In larger urban areas, neighborhoods may to some extent replicate this lack of anonymity, but there are other parts of the urban area where anonymity is ensured. In addition, larger urban areas are often more diverse than small towns, and so visible difference is not such an issue as it is in a small town.

In spite of the conflict caused by the intersecting scales, Kelly self-consciously struggles to "jump scales" (Ruddick 140). Scale gives spatial expression to the meaning of social relations. Jumping scales is therefore the process of giving an action that has a meaning at one scale a meaning at another scale. For example, a kiss has meaning at the scale of the body, but if performed in public it may challenge the interpretation of the town as heterosexual and if performed as part of an organized political protest it may challenge the interpretation of the province or nation as heterosexual. Kelly asserted that: "I'll out myself as soon as I can and be very open about it because I'm not going to be anyone's dirty secret any more. I'm really sick of that and that whole perception of Waterside being really 
straight." She expresses her identity through the scale of her body (T-shirts, for example) and is determined that her presence will have an impact at the scale of the town.

Rather than use their bodies as signifiers, Brenda and Fiona use the function of the town as a site of consumption to challenge its status as a straight space. Fiona remarked: "I was just thinking Mark's Work Warehouse. There is a gay guy. He's pretty obviously there. So it's pretty supportive. You know, so you kind of search those people out. There's a place called Picture Perfect and I am pretty sure it's a dyke who runs it ... Like I would tend to go there, you know. We'll buy from each other kind of stuff." Fiona uses "gaydar," the intuitive sense that another person is also lesbian or gay, to identify retailers she will support. Fiona uses counterassumptions, not necessarily fact, to make the space more gay or lesbian. She inserts herself, and Waterside, into an "imagined community" of lesbians and gays. The term "imagined community," derived from Benedict Anderson, signals a sense of shared connection with the unknown members of a "fictional group" (Weston 257). Fiona presumes that the assistant in Mark's Work Warehouse and the woman in Picture Perfect are both members of the imagined community, and interacts with them accordingly. Fiona's exercise of this practice may be influenced by the fact that she is the only one of the interviewees not born in Waterside or vicinity, but rather grew up in a major city. Other interviewees, such as Dana, might use their "gaydar" but were much more likely to wait until they had verbally established that a woman was "gay" before including her in the "community."

In contrast to these examples of interventions into the space of the town by individuals, when the interviewees are on a group outing their use of the town is more circumspect. Although they frequent a "plain restaurant, a regular restaurant" it is out of town and, as one of the women stated, "that's exactly why it's been chosen." Normally they reserve a private room at this restaurant for their events. When the gay women are in smaller groups (couples or foursomes) they dine in more centrally located restaurants. However, when they are together in the large, women-only group, their visibility as lesbians is dramatically increased and this prompts them to select more remote venues.

In spite of the everyday struggle involved in producing gay women's space in Waterside, few of the women expressed any desire 
to leave. Dana explained her reasons for staying: "'cause my family's here ... Yep. I'm established. At one time I wanted to run away from home, but [laughter] didn't we all? No, I've never even considered moving away." Sam and Martha expressed similar reasons for staying, including proximity to family, cost of living, financial security, and the ability to own a house with a yard. Although none of the interviewees discussed this, it is extremely uncommon for working-class women ever to leave Waterside for an urban location. This too may have influenced their decisions. Others had moved away but subsequently returned. Kelly had returned in order to find work and save money, while living with her mother and sister, but had no intention of staying: "Oh fuck no. Not at all. I hate this place." After living in Toronto for six or seven years, however, Brenda moved back to Waterside, bringing her partner Fiona with her. They did not elaborate on their reasons for returning, but Fiona's ill health coupled with the cost of living elsewhere may have been contributing factors. In Toronto they rented an apartment, whereas in Waterside they own two properties, one of which they rent out.

Some of the interviewees acknowledged an implicit belief that small-town lesbians must go to a big city in order to experience the emancipation only possible in urban spaces. Others had enacted that journey toward emancipation for themselves, expressing the sense that the lesbian and transgender communities in Toronto and Vancouver felt like home. Nevertheless the various ties that brought them back to Waterside challenge two assumptions: first, that migration out of the small town is permanent (see Bell/Valentine, "Queer Country" 117); second, that when lesbians leave urban areas they seek rural feminist utopias (Bell/Valentine, "Queer Country" 118-19; Valentine, "Making Space" 67-69).

The interviewees' experiences suggest that the town is the most complex scale that they have to negotiate. Paradoxically, given that they all referred to it in the same way, the town is also the scale through which divisions between the gay women appear. Some mount conscious challenges to the assumption of Waterside heteronormativity. Others replicate that heteronormativity by choosing out of town social spaces. Attempts to control the contours of gay women's space are threatened by the lack of anonymity in the town, just as the town is unsettled by the presence of gay women's bodies. Nevertheless, the evidence provided by the interviewees 
suggests that it is possible for gay women to create and maintain a space for themselves in small Ontarian towns.

\section{Community}

The preceding sections discussed three scales in some detail. We have argued that through their manipulation of these scales the gay women created a space for their community. The interviewees selfconsciously identify themselves as part of "the community," which they also term the "gay community" and the "women's community." By this they mean that they are part of a group that is defined as a combination of gender, sexual identity, and geographical region. With the possible exception of Fiona, discussed above, their use of the term "community" does not correspond to the "imagined community" discussed by Elwood (16), Lo and Healy (32-33), and Weston (257). Instead it refers to a concrete social network of named individuals, to which access is restricted by its members. Dana regards the community as diverse: "we've got them all in every walk of life here too because Martha, she's in the Armed Forces, Sam's partner, I'm in nursing, we have a teacher, you know, so it's not, oh, and shift workers, and you know that kind of stuff." In addition, the "community" can coalesce in the most unlikely of places; Dana explained: "because how you meet people was, Gina went to a Pampered Chef party, maybe, Tupperware. And Janet was there. And Paula was there. They kind of got talking and so the next time they had their party in the summer Janet and Paula were there. Okay, so there's the next, growth of the community." The "community" is also an exclusive group:

But we were here for almost two years before we really hooked up with them and it almost seems like you really have to kind of get called by somebody ... By invitation only ... this has blown me away, a friend of ours, somebody that we met outside of this group who just moved from Woodridge to here, is gay ... so I called up and said "Do you guys mind if I invite somebody else, a friend of mine who is gay," you know. Oh yah, yah, no problem. And I get a call back two minutes later. Umm, "we had to make sure of something. Is she definitely gay?" I said "yeah." "Is she definitely anonymous? Will she keep everything she hears here anonymous?" I said yeah, you know, that's the condition. (Fiona) 
The careful gatekeeping of the "community" is designed to protect its most vulnerable members. These are the women who are or feel themselves to be at risk of violence, loss of employment, or loss of custody of their children. It also includes the married members of the community. The restrictions on the community are not, then, examples of self regulation as expression of internalized homophobia, which the earlier practices of 'de-dyking' may be. Instead, the gatekeeping is a strategic response to danger, and a conscious act of community building in that all members assume responsibility for protecting the anonymity of the group.

The women expressed pride in the fact that it is a very mobile, active, and physically competent community. While both Sam and Martha referred to routine attempts to minimize their chances of being publicly identified as lesbians, they emphasized that they do not live isolated, inhibited, and solitary lives. As Sam stated, she doesn't "hang back." All the women referred to a plethora of social activities in which they engage with other lesbian residents of Waterside. Sports in particular were identified as an acknowledged way for gay women to meet each other.

Despite the difficulties that these women identified in negotiating their everyday lives as gay women in Waterside, they argue that heterosexist and homophobic discourses and spatial practices have not prevented them from engaging in rich social lives or from developing positive self-images. As Sam made clear, being gay has been "life enhancing." Gay women, according to her, are "adventurous in spirit." She further stated that their sexuality has prompted the women she knows to "do more" with their lives, including building projects, and that she has "never regretted any minute" of her choice to remain in Waterside. She makes a link between her sexuality and her mobility, naturalizing her spatial mobility and active physical life along with that of the other gay women in the community. She sets up an explicit dichotomy with heterosexual women in Waterside. Most heterosexual women there have children (and therefore have no free time) and are in addition subject to intense surveillance by men and other women, just as the gay women feel themselves to be. Nevertheless, Sam implicitly naturalized her spatial mobility and heterosexual women's spatial immobility as a result of their differing sexuality. To fully understand the roots of the dichotomy that Sam invokes we would, ideally, 
examine the socialization of her generation in Waterside into gendered differences in mobility and activity levels.

\section{Conclusions}

Heteronormative sexual discourses and their materializations in space are not just passively accepted but are also actively challenged in Waterside by gay women despite a complete lack of institutional support. The gay women create ruptures in heteronormative sociospatial relations through the very presence of their bodies. Each time the "community" gets together it creates a space at a particular scale. The interviewees suggest that they pick a scale over which they have control, such as a private home, and they control who is granted access to it and under what conditions. In this sense they effectively control what form gay women's space takes in Waterside, and the scale at which it takes place.

The title of this paper, based on Dana's remark that "you're freer if there's nobody around," points to three tentative conclusions. First, the community may have more freedom to produce gay women's space in isolated locations, away from the town and degrees of real and imagined surveillance. Second, as Dana's phrasing - "freer" suggests, the community claims a certain, presumably shifting, degree of freedom even when there are people around. It may be an anonymous group but it, or at least some members of it, have an identifiable presence. Dana's remark about "nobody," although it clearly referred in context to the group holding a party at an isolated rural home, may also signal that some members of the group, such as Kelly or Fiona, have more freedom to signal their sexuality when nobody else from the group is around. Third, while these gay women, as a community, challenge heteronormativity through their use of space, this challenge is not necessarily equally intended by all members of the group. Some may consciously signal their sexuality in an attempt to unsettle the presumed sexual homogeneity of the town, while others may possibly naturalize the heteronormativity of the town, but at once challenge it through their participation in the group.

As we argued at the beginning of this paper, the small sample of interviewees means that our conclusions at this stage are tentative. Nevertheless, our research does raise a number of questions about small towns, the lives of the individual gay women living there, control over space, and lesbian communities. This particular small 
town has at least one large, well-established, and active gay-womenonly community. While the Waterside gay women are clearly not part of a separatist feminist community, they do utilize the rigid gender boundaries of small-town life to create a relatively safe and supportive space for women from which men are excluded. Valentine's work on lesbian separatist communities in the USA suggests that women-only communities (we would except religious orders) tend to evolve from a radical feminist critique of heteropatriarchal oppression ("Making Space" 67). Existing studies of urban or highly visible lesbian spaces do not highlight an absolute division between men and women, but instead map the effects of lesbian concentration on the landscape (Forsyth 51) or discuss how lesbians negotiate and produce urban space in relation to the practices of gay men (Adler/Brenner 25). Gillian Rose argues that feminist separatist spaces have been denigrated since the 1990s as essentialist and exclusionary, but she acknowledges that they have a long history and posits them as temporary "breathing spaces" in women's struggles to form coalitions between groups (153). Valentine assesses the failures of lesbian feminist separatist spaces through bitter conflicts over social differences ("Making Space" 69-74). Does the exclusive, continuously growing, and relatively long life of the gay women's space produced by the interviewees, therefore, offer any lessons for feminist organizing or understandings of separatism?

Our intention now is to explore these questions in continued research and to develop this work in order to think about the production of lesbian and gay women's space at other scales and to consider how these scales intersect. For instance, the work of anthropologist Jo Tacchi examines how radio sound within the home creates a degree of sociability that can link or isolate an occupant from outside social networks. Her work suggests an intriguing dimension for thinking about how scales intersect, and how the use of media creates particular kinds of spaces within the home. This is a particularly promising way to think about how geographically remote communities perceive urban lesbian communities. Similarly, our initial research provides a starting point for considering how the Canadian state, where social relations of sexuality are legislated in particular ways at the national scale, intersects with the gay women's space reproduced in small towns. Do gay women (and heterosexuals) in small towns develop their understanding of what lesbian space 
looks like from Canadian sources, or do they invoke US models such as Provincetown and San Francisco? Hopefully, further qualitative interviews with a larger number of interviewees will elicit answers to these questions. So watch this space.

Many thanks to the interviewees who generously shared their time with us. Thanks to John Plews and two anonymous reviewers for their comments on this article.

\section{Works Cited}

Adler, Sy, and Johanna Brenner. "Gender and Space: Lesbians and Gay Men in the City." International Journal of Urban and Regional Research 16 (1992): 24-34.

Bell, David, Jon Binnie, Julia Cream, and Gill Valentine. "All Hyped Up and No Place To Go." Gender, Place and Culture 1 (1994): 31-47.

, and Gill Valentine. "Queer Country: Rural Lesbian and Gay Lives." Journal of Rural Studies 11 (1995): 113-22. , eds. Mapping Desire: Geographies of Sexualities. London: Routledge, 1995.

Bouthillette, Anne-Marie. "Queer and Gendered Housing: A Tale of Two Neighbourhoods in Vancouver." Ingram, Bouthillette, and Retter 213-32.

Brenner, Neil. "The Urban Question as a Scale Question: Reflections on Henri Lefebvre, Urban Theory and the Politics of Scale." International Journal of Urban and Regional Research 24 (2000): 361-78.

Butler, Judith. Gender Trouble: Feminism and the Subversion of Identity. London: Routledge, 1990.

Cresswell, Tim. In Place, Out of Place: Geography, Ideology, and Transgression. Minneapolis: University of Minnesota Press, 1996.

Elwood, Sarah A. "Lesbian Living Spaces: Multiple Meanings of Home." Journal of Lesbian Studies 4 (2000): 11-27.

Forsyth, Ann. "'Out' in the Valley." International Journal of Urban and Regional Research 21 (1997): 38-62.

Ingram, Gordon Brent, Anne-Marie Bouthillette, and Yolanda Retter, eds. Queers in Space: Communities, Public Spaces, Sites of Resistance. Seattle: Bay, 1997. 
Jay, Elsie. "Domestic Dykes: The Politics of 'Indifference." Ingram, Bouthillette, and Retter 163-68.

Johnston, Lynda, and Gill Valentine. "Wherever I Lay My Girlfriend, That's My Home: The Performance and Surveillance of Lesbian Identities in Domestic Environments." Bell and Valentine 99113.

Lo, Jenny, and Theresa Healy. "Flagrantly Flaunting It?: Contesting Perceptions of Locational Identity among Urban Vancouver Lesbians."Journal of Lesbian Studies 4 (2000): 29-44.

Marston, Sallie A. "The Social Construction of Scale." Progress in Human Geography 24 (2000): 219-42.

McCarthy, Linda. "Poppies in a Wheat Field: Exploring the Lives of Rural Lesbians." Journal of Homosexuality 39 (2000): 7594.

McDowell, Linda. Gender, Identity and Place: Understanding Feminist Geographies. Minneapolis: University of Minnesota Press, 1999.

Podmore, Julie A. "Lesbians in the Crowd: Gender, Sexuality and Visibility along Montréal's Boul. St-Laurent." Gender, Place and Culture 8 (2001): 333-55.

Rose, Gillian. Feminism and Geography: The Limits of Geographical Knowledge. Minneapolis: University of Minnesota Press, 1993. Rothenberg, Tamar. “'And She Told Two Friends': Lesbians Creating Urban Social Space." Bell and Valentine 165-81.

Ruddick, Sue. "Constructing Difference in Public Spaces: Race, Class and Gender as Interlocking Systems. Urban Geography 17 (1996): 132-51.

Smith, Neil. "Homeless/global: Scaling places." Mapping the Futures: Local cultures, global change. Eds. Jon Bird, Barry Curtis, Tim Putnam, George Robertson and Lisa Tickner. London: Routledge, 1993. 87-119.

Tacchi, Jo. "Radio Texture: Between Self and Others." Material Cultures: Why Some Things Matter. Ed. Daniel Miller. London: University of Chicago Press, 1998. 25-45.

Valentine, Gill. "(Hetero)Sexing Space: Lesbian Perceptions and Experiences of Everyday Spaces." Environment and Planning D: Society and Space 11 (1993): 395-413. . "Making Space: Separatism and Difference." Thresholds in Feminist Geography: Difference, Methodology, Representation. 
Eds. John Paul Jones III, Heidi J. Nast, and Susan M. Roberts. Lanham: Rowman \& Littlefield, 1997. 65-76.

. "Negotiating and Managing Multiple Sexual Identities:

Lesbian Time-Space Strategies." Transactions, Institute of British Geographers 18 (1993): 237-48.

. "Out and About: Geographies of Lesbian Landscapes."

International Journal of Urban and Regional Research 19 (1995): 96-111.

Weston, Kath. "Get Thee to a Big City: Sexual Imaginary and the Great Gay Migration." GLQ 2 (1995): 253-77. 